7. Additional Protocol to the Convention on Cybercrime, concerning the criminalisation of acts of a racist and xenophobic nature committed through computer systems. URL: https://www.coe.int/en/web/conventions/full-list//conventions/treaty/189

DOI https://doi.org/10.30525/978-9934-26-074-2-9

\title{
СВОБОДА ЗІБРАНЬ: НОРМАТИВНА РЕГЛАМЕНТАЦІЯ В УКРАЇНІ ТА ПРАКТИКА СВРОПЕЙСЬКОГО СУДУ 3 ПРАВ ЛЮДИНИ
}

\author{
Дахова I. I. \\ кандидатка юридичних наук, \\ доцентка кафедри конституиійного права України \\ Національного юридичного університету імені Ярослава Мудрого \\ м. Харків, Украӥна
}

Право на свободу мирних зібрань $є$ фундаментальним правом, яке передбачене статтею 11 Конвенції про захист прав людини і основоположних свобод, статтею 39 Конституції України, статтею 21 Міжнародного пакту про громадянські і політичні права. Згідно з позицією Конституційного Суду України, це право є однією з конституційних гарантій права громадянина на свободу свого світогляду i віросповідання, думки і слова, на вільне вираження своїх поглядів i переконань, на використання і поширення інформації усно, письмово або в інший спосіб - на свій вибір, права на вільний розвиток своєї особистості тощо. При цьому механізм реалізації вказаного права, особливості підготовки і проведення різних видів масових зібрань, питання щодо їх характеру, суб'єктного складу тощо й досі не знайшли своєї нормативної регламентації в поточному законодавстві України. Європейський суд 3 прав людини (далі - ССПЛ) у відомій справі «Веренцов проти України» від 11.04.2013 р. 3 цього приводу зазначив, шо «хоча Суд погоджується з тим, що державі може знадобитися певний час для прийняття законодавчих актів протягом перехідного періоду, він не може погодитися 3 тим, що затримка у понад двадцять років $\epsilon$ виправданою, особливо коли йдеться про таке фундаментальне право як свобода мирних зібрань». Парламентська асамблея Ради Свропи у своїй Резолюції 2116 (27.05.2016 р.) вказує на відсутність законодавчих положень про свободу зібрань у деяких країнах, у тому числі в України, i 
закликає держави-члени «переглянути чинне законодавство 3 метою приведення його у відповідність до міжнародних документів щодо права на свободу мирних зібрань».

Слід зазначити, що в парламенті періодично спостерігається певна активність щодо законодавчого врегулювання питань, пов'язаних 3 реалізацією права на мирні зібрання, що знаходить своє відображення в появі низки відповідних проектів законів, однак жоден з них на сьогодні не прийнятий Верховною Радою України.

Як відомо, стаття 39 Конституції України передбачає, що про проведення мирних зібрань їх організатори повинні завчасно сповістити органи виконавчої влади чи органи місцевого самоврядування. Щодо вказаної вимоги Венеціанська комісія 21-22.10.2005 р. у висновку щодо тлумачення Керівних принципів ОБСС/БДІПЛ стосовно розробки законів про свободу зібрань у розрізі регулювання громадських зібрань, включно 3 вимогою завчасного повідомлення про демонстрації у громадських місцях ухвалила, що «запровадження процедури завчасного повідомлення про мирні зібрання не обов'язково призводить до порушення цього права. Насправді, у кількох європейських країнах такі режими існують. Як правило, потреба у завчасному повідомленні постає стосовно деяких мітингів або зібрань, наприклад, коли похід планується провести на автомагістралі або коли статичне зібрання планується провести у громадському місці, що вимагає від поліції або інших органів забезпечення можливості для його проведення, а не використання повноважень, які вони можуть мати у встановленому порядку (наприклад, регулювати дорожній рух), для того, щоб завадити заходу». Венеціанська комісія також наголосила на тому, що процедура завчасного повідомлення не повинна бути такою, що зводить нанівець наміри організаторів провести мирну демонстрацію, а отже, опосередковано обмежувати їхні права.

У справі «Веренцов проти України» ССПЛ зазначає, що практика, коли регуляторний орган вимагає завчасного письмового повідомлення про проведення публічних зібрань, $є$ загальноприйнятою. Така вимога $\epsilon$ виправданою з огляду на позитивний обов'язок держави щодо створення необхідних умов для сприяння реалізації свободи зібрань та охорони громадського порядку, громадської безпеки та захисту прав і свобод інших осіб.

Аналогічною є й юридична позиція Конституційного Суду України, висловлена ним у рішенні від 19.04.2001 р. (справа про завчасне сповіщення про мирні зібрання), де він зазначив, що тривалість строків завчасного сповіщення має бути у розумних межах і не повинна обмежувати передбаченого статтею 39 Конституції України права 
громадян на проведення зборів, мітингів, походів і демонстрацій. Такі строки мають слугувати гарантією реалізації цього права громадян. Упродовж цього строку зазначені органи мають здійснити ряд підготовчих заходів, зокрема, для забезпечення безперешкодного проведення громадянами зборів, мітингу, походу чи демонстрації, підтримання громадського порядку, охорони прав і свобод інших людей.

У зв'язку з цим слід загадати позицію ЄСПЛ, висловлену у рішенні у справі «Організація «Платформа «Лікарі за життя» (Plattform «(Artze Fur Das Leben») проти Австрії» від 21.06.1988 р., згідно з якою будь-яка демонстрація може дратувати чи ображати тих, хто виступає проти ідей або вимог, на підтримку яких вона проводиться. Однак у учасників демонстрації повинна тим не менш бути можливість проводити іiї без побоювань бути підданими фізичному насильству з боку своїх опонентів. У демократичному суспільстві право на проведення контрдемонстрації не може виливатись у обмеження реалізації права на демонстрацію. Виходячи з цього, забезпечення істинної, ефективної свободи проведення мирних зібрань не може зводитись лише до зобов'язання держави утриматись від втручання: суто негативна концепція ролі держави у даному випадку суперечить предмету і меті статті 11 Конвенції і вимагає іноді здійснення певних позитивних дій.

Що стосується загрози громадському порядку при проведенні контрдемонстрацій або інших контрзаходів і заборони на цій підставі проведення мирних зібрань, то слід звернути увагу на практику Окружних адміністративних судів. Так, наприклад, Волинський окружний адміністративний суд у Постанові від 20.06.2012 р. у справі № 2a/0370/1890/12, відмовляючи у забороні проведення мирного зібрання, вказав, що «саме по собі проведення заходів різних за змістом в одному місці не свідчить про наявність реальної загрози інтересам національної безпеки та громадського порядку». У рішенні у справі «Фабер проти Угорщини» від 24.07.2012 р. Свропейський Суд вказав, що держава при проведенні контрзаходів має позитивні зобов'язання захищати право на свободу мирних зібрань обох демонстраційних груп і повинна знаходити найменш обмежуючі засоби, які надавали б можливість проводити обидві демонстрації одночасно.

Розглядаючи питання щодо завчасного сповіщення про мирні зібрання, слід звернути увагу на те, що йдеться не про отримання дозволу, а саме про повідомлення про наміри проведення такого заходу, на відміну від вимог законодавства СРСР (i, відповідно, УРСР), яке передбачало саме дозвільний порядок проведення мирних зібрань. Серед прикладів «реагування» держави на проведення несанкціонованих зібрань можемо згадати трагічні події 1962 року в Новочеркаську, коли 
за наказом органів влади було розстріляно учасників мирного мітингу, що вимагали реалізації їх соціальних прав.

Чи може мирне зібрання бути проведене спонтанно, без завчасного сповіщення про його проведення органів публічної влади? Українське законодавство не містить відповіді на це питання, однак згідно 3 позицією ЄСПЛ, висловленою в рішенні «Веренцов проти України», не слід вимагати, щоб демонстранти, які здійснюють акцію протесту в індивідуальному порядку, надсилали органам влади завчасні повідомлення про намір провести демонстрацію. У разі, якщо до особи, яка проводить індивідуальну акцію, приєднується інша особа або особи, такий захід слід розглядати як стихійне зібрання. До того ж, у Спільному висновку Венеціанської комісії, Генерального директорату з прав людини і законності Ради Свропи і Бюро ОБСС з демократичних установ і прав людини на два проекти законів України про гарантії свободи мирних зібрань (Венеція, 14-15 жовтня 2016 р.) вказується, що відсутність повідомлення не повинна призводити до автоматичної заборони зборів.

Особливої уваги потребує вирішення питання про визначення характеру заходу, що проводиться, адже захищається лише право на мирні зібрання. Які ознаки (відсутність ознак) свідчать про мирний характер масового заходу? До таких ознак слід віднести відсутність зброї або заздалегідь заготовлених для нанесення тілесних ушкоджень предметів у учасників зібрання, відсутність підбурювань до насильства 3 боку організаторів та учасників масових заходів, а також дій, спрямованих на вчинення насильства. У рішенні у справі «Чернега та інші проти України» від 18.06.2019 р. ССПЛ вказує, що термін «мирне» слід поширити і на поведінку, що може нервувати або ображати осіб, які не погоджуються з ідеями або заявами, підтриманими цим зібранням, $\mathrm{i}$ навіть на поведінку, яка спрямована на навмисне перешкоджання або створення перешкод діяльності третіх осіб. Наприклад, зібрання, пов'язане виключно з пасивним опором, слід вважати «мирним».

Якщо зібрання задовольняє вказаному головному критерію мирного характеру зібрань, це приводить до виникнення позитивних обов'язків державних органів влади, пов'язаних з правом на свободу мирних зібрань. 